\title{
SLUDGE LUMPUR AKTIF, SAMPAH DAPUR DAN KOTORAN SAPI SEBAGAI BAHAN BAKU BIOGAS PORTABEL
}

\author{
Sri Widyastuti ${ }^{1)}$ Sri Mulyani ${ }^{2)}$ \\ 1) 2) Program Studi Teknik Lingkungan, Fakultas Teknik Sipil dan Perencanaan \\ Universitas PGRI Adi Buana Surabaya \\ Email : rafirudi@yahoo.co.id
}

\begin{abstract}
Abstrak
Limbah padat non medis dan sludge lumpur aktif yang dihasilkan dari kegiatan pelayanan di Rumah Sakit belum banyak dimanfaatkan. Pemanfaatan dilakukan dengan mencampur sludge lumpur aktif Instalasi Pengolahan Air Limbah (IPAL), sampah dapur dan kotoran sapi sebagai bahan baku pembuatan biogas portabel. Reaktor biogas portabel berupa drum plastik berbahan High Density Polyethylene (HDPE) volume 150 liter. Pengkajian pengolahan limbah sludge ini dilakukan dengan tiga variasi. Proses pembuatan biogas reaktor portabel dilakukan dengan mencampur bahan baku yaitu slude lumpur aktif IPAL, sampah dapur, dan kotoran sapi dengan komposisi sesuai variasi yang ditentukan dan ditambahkan air dengan perbandingan campuran dan air $1: 1$. Mengaduk semua campuran dan selanjutnya memasukkan ke dalam digester sampai $2 / 3$ volume digester selama 30 hari. Hasil uji nyala berturut-turut variasi I,II dan III adalah 91 detik, 264,7 detik dan 381,7 detik. Pupuk organik cair yang dihasilkan dari proses fermentasi yang memiliki kandungan C Organik, N dan Salmonella sesuai SNI Pupuk Organik Cair Tahun 2011 adalah variasi I dan III. Variasi I tidak memenuhi karena nilai C organik dan $\mathrm{N}$ dibawah batas minimum dan Salmonella diatas batas maksimum. Kesimpulan dari studi ini adalah variasi sludge lumpur aktif IPAL(50\%), sampah dapur(20\%) dan kotoran sapi(30\%) menghasilkan pupuk organik cair terbaik untuk parameter $\mathrm{C}$ Organik, $\mathrm{N}$ dan Salmonella.
\end{abstract}

Kata Kunci: Biogas, Kotoran Sapi, Pupuk Organik Cair, Sampah Dapur, Sludge Lumpur Aktif IPAL

\begin{abstract}
Non-medical solid waste and activated sludge sludge generated from hospital service activities have not been widely used. Utilization is carried out by mixing activated sludge sludge, Wastewater Treatment Plant (WWTP), kitchen waste and cow dung as raw material for making portable biogas. Portable biogas reactor in the form of a plastic drum made of High Density Polyethylene (HDPE) volume of 150 liters. The study of sludge waste treatment is carried out with three variations. The process of making portable reactor biogas is done by mixing raw materials, namely sludge of WWTP active sludge, kitchen waste, and cow manure with the composition according to the specified variation and adding water with a mixture of 1: 1 mixture and water. Stir all mixtures and then put into the digester up to $2 / 3$ the volume of the digester until 30 days. The results of the flame test, respectively variations I, II and III are 91 seconds, 264.7 seconds and 381.7 seconds. Liquid organic fertilizers produced from fermentation processes which contain Organic $C, N$ and Salmonella according to SNI for Liquid Organic Fertilizer in 2011 are variations I and III. Variation I does not meet because the value of organic $C$ and $N$ is below the minimum limit and Salmonella is above the maximum limit. The conclusion of the study is variations in IPAL sludge active sludge (50\%), kitchen waste (20\%) and cow dung (30\%) produce the best liquid organic fertilizer for the parameters of Organic $C, N$ and Salmonella.

Keywords: Biogas, Active Sludge IPAL, Kitchen Garbage, Cow Manure, Liquid Organic Fertilizer
\end{abstract}




\section{PENDAHULUAN}

Limbah padat non medis yang dihasilkan RSU Haji Surabaya sebagian besar merupakan sampah organik yang berasal dari Instalasi Gizi (sampah dapur), administrasi, kantin, taman dan kegiatan pengunjung. Sampah organik yang berasal dari sampah dapur berupa kulit sayur-sayuran, kulit buah-buahan dan sisa makanan. Sampah organik tersebut merupakan limbah padat yang masih bisa dimanfaatkan, salah satunya sebagai bahan baku pembuatan biogas. Berdasarkan Keputusan Menteri
Kesehatan Republik Indonesia No.1204/MENKES/SK/X/2004, tentang Persyaratan Kesehatan Lingkungan Rumah Sakit, limbah padat non medis adalah limbah padat yang dihasilkan dari kegiatan di Rumah Sakit di luar medis yang berasal dari dapur, perkantoran, taman, dan halaman yang dapat dimanfaatkan kembali apabila ada teknologinya. Jumlah sampah dapur yang dihasilkan Instalasi Gizi selama 7 hari pada tanggal 18 Juli 2016 - 24 Juli 2016 dapat dilihat pada gambar 1 .

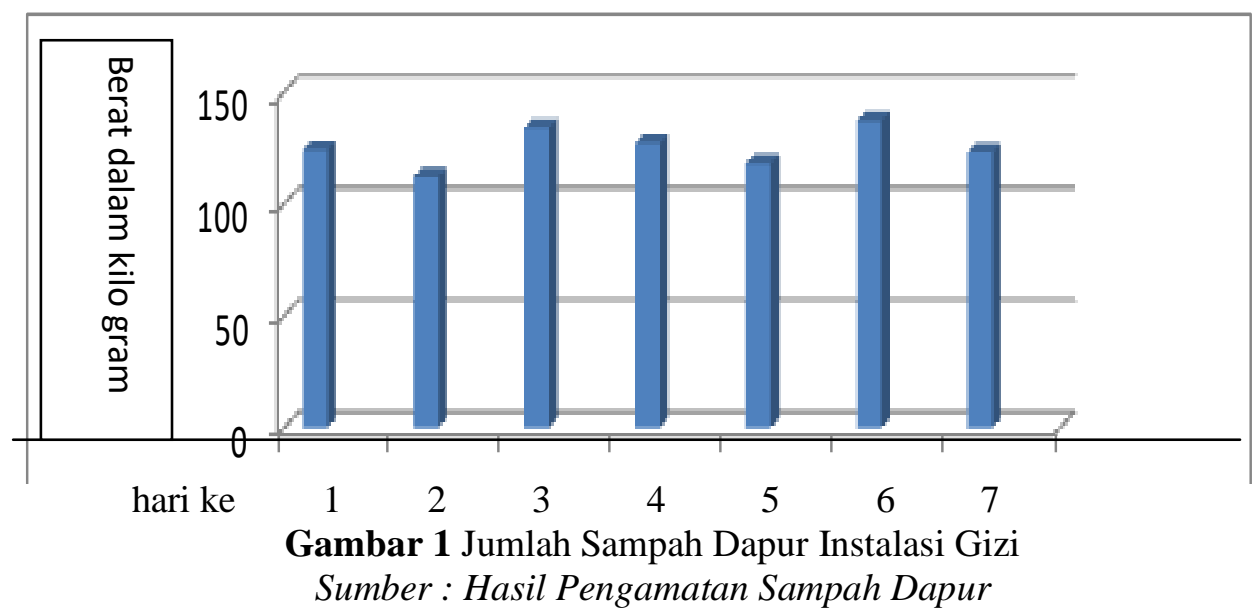

Biogas merupakan gas yang dihasilkan oleh aktivasi anaerobik atau fermentasi dari bahan-bahan organik seperti limbah domestik, kotoran hewan, sampah biodegradable atau setiap limbah organik yang biodegradable dalam kondisi anaerobik. Kandungan utama dalam biogas adalah metana dan karbon dioksida. Biogas yang dihasilkan oleh aktivitas anaerobik sangat populer digunakan untuk mengolah limbah biodegradable karena bahan bakar dapat dihasilkan sambil menghancurkan bakteri patogen dan sekaligus mengurangi volume limbah buangan.

Proses pembuatan biogas di pengaruhi oleh beberapa faktor, diantaranya adalah temperatur, $\mathrm{pH}$, biomassa, pengadukan dan starter. Temperatur paling baik bakteri metanogenik yang bersifat mesofilik adalah $35^{\circ} \mathrm{C}$, dan termofilik adalah 50 ${ }^{\circ}-60^{\circ} \mathrm{C}$ (Gerardi , 2003 ) dalam ( Ogbonna, 2015). pH pembentukan metana berkisar antara 5,5-8,5, dengan interval terbaik pada rentang 7,0-8,0 untuk kebanyakan bakteri metanogen (Seadi et al, 2008). Tahap pertama, zat organik akan diurai menjadi asam lemah dengan bantuan bakteri pembentuk asam. Bakteri ini akan menguraikan sampah pada tingkat hidrolisis dan pembentukkan asam. Proses hidrolisa akan menguraikan senyawa kompleks atau senyawa rantai panjang dari lemak, protein, karbohidrat menjadi senyawa yang sederhana. Selanjutnya terjadi reaksi asidifikasi yaitu pembentukan asam dari senyawa sederhana (Pambudi, 2008) dalam (Mujahidah et al., 2013).

Pengolahan limbah cair di RSU Haji Surabaya menggunakan dua sistem pengolahan. Pertama sistem pertumbuhan menempel secara aerobic Rotary Biological Contactor (RBC) dan kedua dengan proses Suspended Growth System (sistem pertumbuhan tersuspensi). Pada pengolahan yang kedua terbentuk lumpur aktif (activated sludge processes), lumpur aktif yang 
terbentuk banyak mengandung bakteri, sehingga lumpur aktif juga bisa digunakan sebagai starter dalam pembuatan biogas (Rahmi, 2010). Adapun hasil uji laboratorium outlet lumpur aktif dapat dilihat pada tabel 1 .

Tabel 1. Hasil Uji Laboratorium Outlet Lumpur Aktif

\begin{tabular}{clcc}
\hline NO & PARAMETER & HASIL UJI & BAKU MUTU \\
\hline & BAKTERIOLOGI & & \\
\hline 1. & Kuman Gol.Koli & $4.200 / 100 \mathrm{ml}$ & $10.000 / 100 \mathrm{ml}$ \\
\hline & FISIKA & & \\
\hline 2 & Suhu & $27,6^{\circ} \mathrm{C}$ & $30^{\circ} \mathrm{C}$ \\
\hline 3 & TSS & $5,50 \mathrm{mg} / \mathrm{l}$ & $30 \mathrm{mg} / 1$ \\
\hline & KIMIA & 7,44 & $6-9$ \\
\hline 4 & pH & $10,7 \mathrm{mg} / 1$ & $30 \mathrm{mg} / 1$ \\
\hline 5 & BOD & $17,3 \mathrm{mg} / \mathrm{l} / 1$ & $80 \mathrm{mg} / \mathrm{l}$ \\
\hline 6 & COD & $0,0498 \mathrm{mg} / \mathrm{l}$ & $0,1 \mathrm{mg} / \mathrm{l}$ \\
\hline 7 & $\mathrm{NH}_{3}-\mathrm{N}$ & $0,537 \mathrm{mg} / \mathrm{l}$ & $2 \mathrm{mg} / 1$ \\
\hline 8 & $\mathrm{PO}_{4}(\mathrm{Ortho})$ & & \\
\hline
\end{tabular}

Sumber : Hasil Uji Outlet Lumpur Aktif

Penelitian ini menggunakan sludge lumpur aktif yang berasal dari IPAL dengan campuran sampah dapur dan kotoran sapi sebagai bahan baku biogas. Reaktor dalam penelitian berupa digester yang terbuat dari drum plastik dengan volume 150 liter. Reaktor diisi bahan baku dengan perbandingan bervariasi yang bertujuan untuk membandingkan hasil akhir mana yang memiliki komposisi terbaik dalam menghasilkan biogas.

\section{METODE PENELITIAN}

Variabel yang digunakan dalam penelitian ini

1) Variabel Bebas terdiri tiga variasi yaitu : variasi I Sludge lumpur aktif IPAL 30\% : Sampah dapur 20\% : Kotoran sapi $50 \%$, variasi II Sludge lumpur aktif IPAL 40\% : Sampah dapur $20 \%$ : Kotoran sapi $40 \%$,variasi III Sludge lumpur aktif IPAL 50\% : Sampah dapur 20\% : Kotoran sapi $30 \%$

2) Variabel Terikat ini adalah :

Tekanan gas yang dihasilkan, Lama waktu yang dibutuhkan mulai dari pencampuran awal sampai dengan menghasilkan gas, $\mathrm{C}$ Organik, $\mathrm{N}$ dan Salmonella pupuk organik cair (Standart SNI pupuk organik cair).
Untuk memperoleh data yang diperlukan dalam penelitian ini, maka ditempuh langkah-langkah sebagai berikut :

1) Peralatan dan Bahan Penelitian

a. Alat-alat : Reaktor (digester) menggunakan drum plastik dengan volume 150 liter (gambar 1). Adapun peralatan lain yang diperlukan terdiri dari : Bak pencampur, Bak (corong) pemasukan bahan, Bejana pencerna (memiliki pipa/kran keluaran gas), Bejana pencuci dan penampung gas , Alat pengaduk/pencampur, Alat penusuk, Alat pengatur tekanan dengan metode kolom air (manometer),

b. Bahan : Sampah dapur, Sludge lumpur aktif, Kotoran sapi

2) Tahapan Pengumpulan Data

a. Seeding

Langkah-langkah yang dilakukan untuk tahap seeding ini yaitu dengan mengambil kotoran sapi sebanyak $1 \mathrm{~kg}$, selanjutnya tambahkan 1liter limbah cair segar dari IPAL Rumah Sakit. Langkah lakukan setiap hari, lakukan selama sepuluh hari pada sepuluh erlenmeyer ukuran 2 liter 
sehingga didapat volume akhir 20 liter.

b. Aklimatisasi

Langkah-langkah yang dilakukan untuk tahap aklimatisasi ini yaitu dengan melakukan proses aklimatisasi biomassa, digunakan untuk mendegradasi kandungankandungan karbohidrat, lemak dan minyak yang terdapat pada limbah cair (Santoso 2010). Proses aklimatisasi dilakukan dengan metoda buang dan isi (fill and draw) yaitu dengan membuang supernatan sebanyak $200 \mathrm{ml}$ setiap hari kemudian ditambahkan $200 \mathrm{ml}$ limbah cair segar. Proses aklimatisasi berlangsung pada kondisi operasi suhu ruang. Selama proses aklimatisasi dilakukan analisa terhadap nilai $\mathrm{pH}$.

c. Pembuatan gas Bio

Mengumpulkan sampah dapur kemudian dibersihkan dari sampah anorganik (plastik, kertas dan lain-lain) agar dapat mempercepat pembentukan gas bio. Menimbang sampah dapur sesuai dengan komposisi masingmasing variasi. Menggiling sampah dapur dengan blender untuk mendapatkan ukuran sampah yang lebih halus, agar mempermudah proses pencernaan dalam fermentasi pembentukan gas bio (Mshandete A, Bjornsson, Kivaisi AK, Rubindamayugi MST, Mattiason B., 2006). Mencampur bahan baku yaitu slude lumpur aktif IPAL, sampah dapur, dan kotoran sapi dengan komposisi sesuai variasi yang ditentukan dan ditambahkan air dengan perbandingan campuran dan air 1 : 1. Mengaduk semua campuran dan selanjutnya memasukkan ke dalam digester sampai $2 / 3$ volume digester. Memastikan bahwa digester dalam posisi tertutup rapat dan kedap, dengan tujuan agar tidak kemasukkan benda asing dari luar, yang dapat mempengaruhi proses dan hasil dari gas bio. Pengamatan tekanan gas bio yang dihasilkan dilakukan setiap pagi pukul 09.00 wib selama 30 hari. Melakukan uji nyala untuk memastikan bahwa gas yang terbentuk adalah $\mathrm{CH}_{4}$ dan bukan $\mathrm{CO}_{2}$.

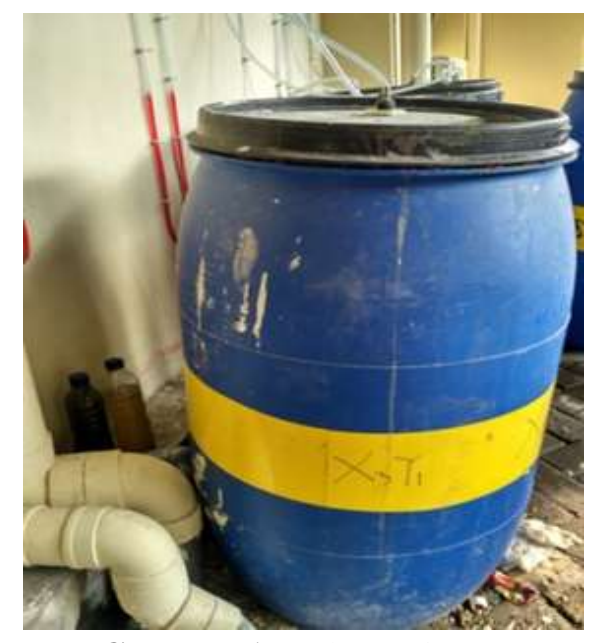

Gambar 1. Rektor Biogas

\section{Cara Pengukuran Tekanan Gas Bio:}

Memasang pipa pada lubang penghasil gas, kemudian ujung dari pipa tersebut letakkan pada papan. Membentuk ujung pipa tersebut menyerupai huruf "U" pada papan. Mengisi pipa tersebut dengan air warna sampai mendapatkan ukuran air vertikal antara sisi ujung pipa huruf "U" tersebut. Memasang penggaris pada sisi 
pipa, dengan tanda start awal $0 \mathrm{ml}$ pada ujung pipa berisi air warna. Mengamati perubahan kenaikan atau penurunan air warna. Dan membacaan tekanan gas dengan menghitung pada penggaris yang telah terpasang pada sisi ujung pipa. Membaca tekanan gas bio pada kolom air menggunakan satuan ml. Pembacaan tekanan dilakukan setiap pagi pukul 09.00 wwib, pembacaan dilakukan selama 30 hari untuk setiap jenis sampel.

\section{Cara Pelaksanaan Uji Nyala}

Pada hari ke 30 dilakukan uji nyala pada masing-masing Reaktor. Menghubungkan selang plastik output gas dengan kompor gas.Setelah api menyala menghitung lama waktu nyala dengan menggunakan stopwacth. Uji nyala ini dilakukan untuk memastikan bahwa gas yang terbentuk adalah gas $\mathrm{CH} 4$ dan bukan gas $\mathrm{CO} 2$.

\section{Cara Pengujian Pupuk Organik Cair}

Dalam penelitian ini pengujian C Organik pada pupuk organik cair menggunakan metode kurmies dan alat yang dipakai adalah spektrophotometer, sedangkan satuan dari hasil uji adalah persen (\%). Untuk pengujian $\mathrm{N}$ pada pupuk organik cair menggunakan metode $\mathrm{H}_{2} \mathrm{SO}_{4}+\mathrm{H}_{2} \mathrm{O}_{2}$ dan alat yang dipakai adalah destilator, sedangkan satuan dari hasil uji adalah persen (\%).

Pada peng-ujian identifikasi bakteri Salmonella metode yang digunakan adalah metode analisa secara kualitatif. Tujuan dari metode ini untuk mengetahui ada tidaknya suatu mikroorganisme. Pengujian pupuk organik cair dilakukan di laboratorium Terpadu Poltekkes Kemenkes Surabaya. Sedangkan analisa yang dilakukan adalah analisa terhadap kandungan $\mathrm{C}$ Organik, N dan Salmonella. - Tujuan dari pengujian ini adalah membandingkan hasil laboratorium apakah sesuai dengan SNI pupuk organik cair. Dalam penelitian ini mengacu pada Peraturan Menteri Pertanian Nomor 70/Permentan/SR.140/10/2011.

\section{HASIL DAN PEMBAHASAN Pengamatan Tahap Seeding} Seeding dilakukan dengan mengambil kotoran sapi sebanyak $1 \mathrm{~kg}$, selanjutnya tambahkan 1 liter limbah cair IPAL Rumah Sakit, dilakukan setiap hari, yang dilakukan selama sepuluh hari pada sepuluh erlenmeyer ukuran 2 liter sehingga didapat volume akhir 20 liter. Dalam pengamatan setiap hari, digester melepas gas dan bau kurang sedap yang menandakan bahwa proses seeding berjalan dengan baik.

\section{Pengamatan Tahap Aklimatisasi}

Tahap aklimatisasi merupakan tahap adaptasi mikroorganisme terhadap limbah cair atau substrat yang akan dipakai. Tahap aklimatisasi ini bertujuan untuk membiasakan mikroorganisme terhadap limbah cair agar mikroorganisme berkembang biak dan tidak mengalami gangguan atau kematian pada saat diberlakukan dengan limbah cair yang akan diolah (Ahmad, 2004). Tahap aklimatisasi ini dilakukan selama 14 hari. Selama tahap aklimatisasi, $\mathrm{pH}$, dianalisa untuk masing-masing pencerna anaerob. Analisa ini dilakukan untuk mengetahui apakah tahap aklimatisasi telah tercapai atau tidak (Ahmad, 20014). Pada tahap aklimatisasi perlu dilakukan pengamatan terhadap $\mathrm{pH}$ keluaran pencerna anaerob untuk mengetahui kondisi mikroorganisme di dalam pencerna anaerob. Selama tahap aklimatisasi ini, $\mathrm{pH}$ diukur setiap hari.

\section{Pengamatan Tekanan Gas Pada Manometer Selang "U"}

Pada ketiga variasi yang berbeda dilakukan tiga kali pengulangan untuk setiap variasi. Pada dasarnya proses pembuatan biogas untuk skala penelitian atau individu membutuhkan waktu fermentasi selama 18-21 hari dengan perbandingan campuran bahan baku adalah 1:1. Penelitian ini dilakukan selama 30 hari dengan bahan baku sludge lumpur aktif IPAL, sampah dapur dan kotoran sapi.

Dari pengamatan pada manometer terlihat bahwa pada variasi I mulai terjadi pembentukan gas pada hari ke 5, variasi II mulai terjadi pembentukan gas pada hari ke-3 dan variasi III mulai terjadi pembentukan gas pada hari ke-2. 
Dari ketiga variasi yang memiliki waktu tercepat berturut-turut variasi III, II dan I. Dari setiap variasi terlihat bahwa tekanan gas optimum terjadi pada hari ke-17 dan hari ke-19. Namun tidak dapat diketahui manakah diantara variasi II dan variasi III yang tercepat dalam menghasilkan tekanan yang maksimum karena variasi II dan variasi III menghasilkan tekanan maksimum pada hari yang sama yaitu hari ke 19. Karena itu penelitian ini dapat digunakan sebagai dasar untuk penelitian selanjutnya yaitu dengan menggunakan bahan yang sama tetapi dengan memvariasikan perbandingan campuran. Hal ini sama dengan penelitian yang dilakukan oleh Anis Tristaningsih dan Sri Widyastuti (2015) yaitu tekanan gas yang paling tinggi pada setiap percobaan,dihasilkan dari proses penguraian sampah sayur, sampah daun dengan kotoran sapi yaitu variasi 1 (campuran sampah dapur 30\% sampah daun 20\% dengan kotoran sapi $50 \%$ ),dimana rentang tekanannya mencapai 33-38 cm kolom air. Sedangkan tekanan gas yang paling rendah pada setiap percobaan,dihasilkan dari proses penguraian sampah dapur $55 \%$, sampah daun $10 \%$ dengan kotoran sapi 35\%), dimana rentang tekanannya hanya mencapai $22-23 \mathrm{~cm}$ kolom air.

Perubahan kolom air pada manometer menunjukan bahwa reaktor biogas dengan tiga variasi berbeda dalam penelitian ini dapat menghasilkan gas bio. Hal ini disebabkan karena ketiga bahan baku yang digunakan dalam penelitian ini yaitu sludge lumpur aktif IPAL, sampah dapur dan kotoran sapi banyak mengandung bakteri alami yang mendukung dalam proses pembentukan gas bio. Selain itu sludge lumpur aktif IPAL juga menjaga keseimbangan $\mathrm{pH}$ sehingga membantu proses fermentasi dalam pembuatan biogas.

Sedangkan hubungan antara waktu dan tekanan gas kolom air menunjukkan pada hari ke-1 sampai hari ke-30 tekanan gas terus meningkat sampai pada titik optimum kemudian menurun. Untuk melihat hubungan waktu dan tekanan gas yang dihasilkan oleh reaktor dengan variasi berbeda dapat dilihat pada Gambar 2.

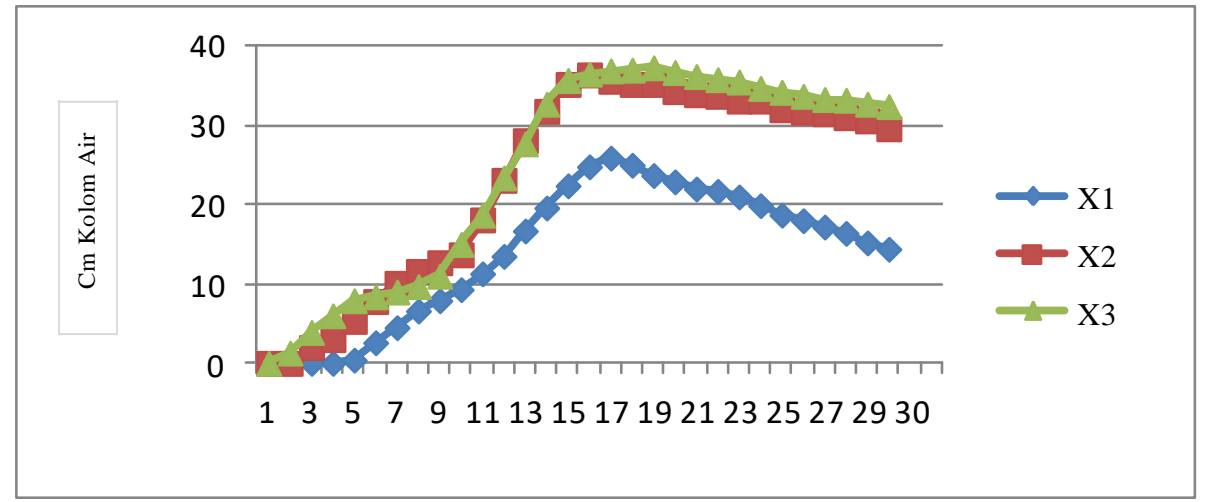

Gambar 2. Grafik Hubungan Waktu Dan Tekanan Gas Pada Reaktor Dengan Variasi Berbeda Sumber : Hasil PengamatanTekanan Gas

Keterangan :

$\mathrm{X}_{1}=$ Variasi I (sludge lumpur aktif IPAL 30\%, sampah dapur 20\% \& kotoran sapi 50\%) $\mathrm{X}_{2}=$ Variasi II(sludge lumpur aktif IPAL $40 \%$, sampah dapur 20\% \& kotoran sapi 40\%) $\mathrm{X}_{3}=$ VariasiIII(sludge lumpur aktif IPAL 50\%, sampah dapur 20\% \& kotoran sapi 30\%) 
Gambar 2 menunjukkan ketiga reaktor biogas dengan variasi berbeda dapat menghasilkan gasbio karena menggunakan bahan baku yang mengandung bakteri alami. Variasi III menunjukkan perubahan tekanan gas pada manometer lebih awal dan memiliki tekanan gas optimum tertinggi, hal ini dimungkinkan karena sludge lumpur aktif IPAL memiliki sifat alkali. Alkalinitas sludge lumpur aktif IPAL membantu mempertahankan $\mathrm{pH}$ agar tidak mudah berubah yang disebabkan oleh penambahan asam. Selain itu, alkalinitas juga mempengaruhi pengolahan zat-zat kimia dan biologi serta dibutuhkan sebagai nutrisi bagi mikroba.

Salah satu penelitian tentang biogas dilakukan oleh Sutrisno (2010) yaitu pembuatan biogas dari bahan sampah sayuran (kubis, kangkung dan bayam). Pada penelitiannya Sutrisno (2010) menggunakan sampah sayuran seperti kubis, kangkung dan bayam sebagai bahan baku pembuatan biogas untuk ditentukan bahan manakah dari ketiga bahan tersebut yang menghasilkan tekanan gas tertinggi dan juga berapa lama waktu yang dibutuhkan oleh masing-masing bahan untuk memproduksi gas.

Penelitian yang dilakukan oleh Sutrisno (2010) dengan penelitian ini memiliki hasil yang berbeda apabila ditinjau dari waktu menghasilkan gas. Dalam penelitian Sutrisno (2010) gas berproduksi maksimum selama 152 jam atau sekitar 6 hari, sedangkan dalam penelitian ini gas berproduksi maksimum pada rentang hari ke-17 dan hari ke-19 setelah proses fermentasi. Hal ini disebabkan karena dalam penelitiannya Sutrisno (2010) menggunakan cairan EM4 untuk mempercepat proses fermentasi sehingga waktu yang dibutuhkan untuk memproduksi gas lebih sedikit.

\section{a. Uji Nyala Biogas}

Uji nyala untuk memastikan bahwa gas yang dihasilkan bukan $\mathrm{CO}_{2}$ melainkan gas $\mathrm{CH}_{4}$. Langkah pertama adalah meghubungkan selang output dari digester dengan kompor gas yang sudah dimodifikasi sedemikian rupa. Sebelum kompor dinyalakan siapkan stopwatch sehingga pada saat kompor mulai dihidupkan bisa dihitung lama waktu kompor menyala. Hasil uji nyala dapat dilihat pada tabel 3.

Tabel 3. Uji Lama Nyala Api Biogas

\begin{tabular}{|c|c|c|c|c|c|c|c|}
\hline \multirow{2}{*}{ No } & \multirow{2}{*}{ Kode } & \multicolumn{3}{|c|}{ Uji Nyala (detik) } & \multirow{2}{*}{ Total } & \multicolumn{2}{c|}{ Rata-Rata Lama Uji Nyala } \\
\cline { 3 - 5 } \cline { 6 - 7 } & $\mathbf{Y}_{\mathbf{1}}$ & $\mathbf{Y}_{\mathbf{2}}$ & $\mathbf{Y}_{\mathbf{3}}$ & & Detik & Menit \\
\hline 1 & $\mathrm{X}_{1}$ & 93 & 89 & $\infty$ & 182 & 91 & 1 menit 31 detik \\
\hline 2 & $\mathrm{X}_{2}$ & 273 & 242 & 279 & 794 & 264,7 & 4 menit 24,7 detik \\
\hline 3 & $\mathrm{X}_{3}$ & 374 & 378 & 393 & 1145 & 381,7 & 6 menit 21,7 detik \\
\hline
\end{tabular}

Sumber : Hasil Pengamatan Uji Nyala Biogas

Hasil uji lama nyala variasi III memiliki lama nyala api paling lama. Pada variasi I pengulangan 3 tidak terdeksi atau tidak menghasilkan nyala api. Hal ini karena terjadi kebocoran dan gas yang dihasilkan berbau menyengat yang dimungkinkan kandungan gas $\mathrm{H}_{2} \mathrm{~S}$ cukup tinggi.
Bahan baku dari pembuatan biogas sangat berpengaruh dengan gas yang dihasilkan. Hubungan antara bahan baku pembuatan biogas dengan lama nyala api yang dihasilkan dapat dilihat pada Gambar 3. 


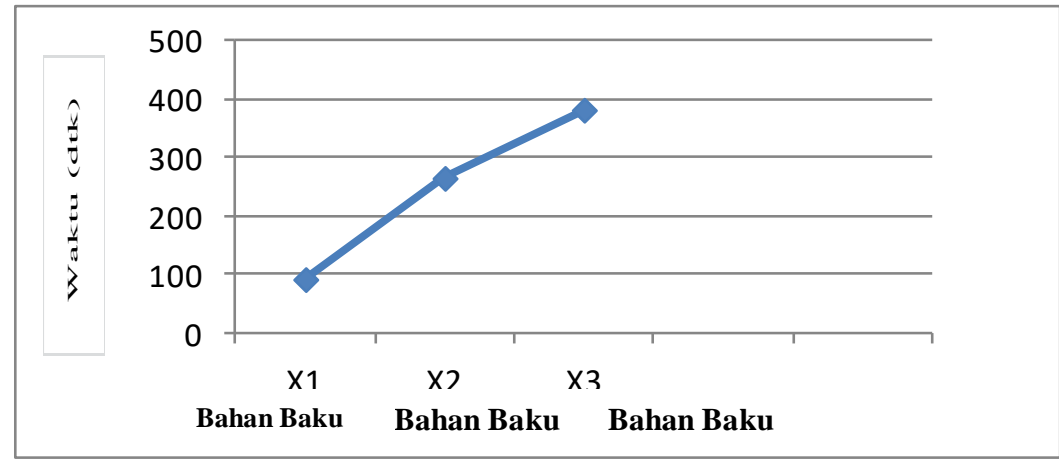

Gambar 3. Grafik Hubungan Bahan Baku Biogas Dengan Lama Nyala Api Sumber : Hasil PengamatanUji Nyala Biogas

Berdasarkan variasi persen (\%) bahan baku dalam penelitian ini dapat diketahui semakin tinggi persentase sludge lumpur aktif IPAL (50\%) menghasilkan gas optimum terbaik dan uji nyala api terlama. Hal ini disebabkan sludge lumpur aktif IPAL bersifat alkali. Dalam proses pembentukan gas bio bakteri berkembang dengan baik pada keadaan yang agak asam $(\mathrm{pH}$ antara 6,6 - 7,4) dan $\mathrm{pH}$ tidak boleh di bawah 6,2. Pada tahap pembentukan asam akan menurunkan $\mathrm{pH}$ awal. Jika penurunan ini cukup besar akan dapat menghambat aktivitas mikroorganisme penghasil metana. Karenanya alkalinitas dari sludge lumpur aktif IPAL sangat berperan dalam menjaga kondisi $\mathrm{pH}$ selama proses berlangsung.

b. Hasil Uji Laboratorium

Dari proses pembuatan biogas akan dihasilkan sisa yang bisa dimanfaatkan sebagai pupuk organik cair. Pemeriksaan pupuk organik cair dilakukan di Laboratorium Terpadu Poltekkes Kemenkes Surabaya. Sebelum dilakukan pemeriksaan pupuk organik cair di saring terlebih dahulu dan dimasukkan dalam botol sampel yang diberi label identitas. Selanjutnya sampel sisa yang dihasilkan dari biogas dikirim ke laboratorium untuk dilakukan pemeriksaan. Adapun hasil pemeriksaan sisa proses biogas yang dapat dimanfaatkan sebagai pupuk organikcair dapat dilihat pada tabel 4.

Tabel 4. Hasil Pengukuran Pupuk Organik Cair Proses Pembuatan Biogas Portabel

\begin{tabular}{|c|c|c|c|c|c|c|c|}
\hline \multirow{2}{*}{ No } & \multirow{2}{*}{$\begin{array}{l}\text { Kode } \\
\text { Sampel }\end{array}$} & \multicolumn{3}{|c|}{$\begin{array}{c}\text { Hasil Pengukuran Pupuk } \\
\text { Organik Cair }\end{array}$} & \multicolumn{3}{|c|}{ Baku Mutu } \\
\hline & & $\begin{array}{c}\text { C organik } \\
(\%)\end{array}$ & $\begin{array}{l}N \\
(\%)\end{array}$ & $\begin{array}{c}\text { Salmonella } \\
\text { (MPN/ml) }\end{array}$ & $\begin{array}{c}\text { C organik } \\
(\%)\end{array}$ & $\begin{array}{c}N \\
(\%)\end{array}$ & $\begin{array}{l}\text { Salmonella } \\
\text { (MPN/ml) }\end{array}$ \\
\hline 1. & $\mathrm{X}_{1}$ & 4,69 & 2,05 & $3,7 \times 10^{2}$ & $\min 6$ & $3-6$ & $\operatorname{maks} 10^{2}$ \\
\hline 2. & $\mathrm{X}_{2}$ & 8,28 & 3,12 & $8,8 \times 10^{1}$ & $\min 6$ & $3-6$ & maks $10^{2}$ \\
\hline 3. & $X_{3}$ & 12,23 & 4,39 & $4,3 \times 10^{1}$ & $\min 6$ & $3-6$ & maks $10^{2}$ \\
\hline
\end{tabular}

Sumber : Hasil Uji Laboratorium Pupuk Organik Cair

Kualitas dari pupuk cair yang dihasilkan menunjukkan variasi II dan variasi III memenuhi SNI, karena untuk parameter $\mathrm{C}$ Organik dan $\mathrm{N}$ melebihi SNI sedangkan parameter Salmonella kurang dari SNI. Untuk variasi I tidak memenuhi SNI karena parameter C Organik dan N kurang dari SNI, sedangkan parameter Salmonella melebihi SNI. Hasil ini sesuai dengan penelitian Anis Tristaningsih dan Sri Widyastuti 
(2015) bahwa kandungan lindi hasil fermentasi sampah tersebut terdapat bakteri pathogen yaitu salmonella sehingga tidak dapat digunakan sebagai pupuk organik cair karena belum memenuhi standart SNI 197030-2004.

Dari hasil tersebut dapat disimpulkan semakin besar persetase (\%) sludge lumpur aktif IPAL sebagai bahan baku biogas semakin baik kualitas pupuk organik cair yang dihasilkasn. Sedangkan semakin sedikit persentase (\%) sludge lumpur aktif IPAL yang digunakan sebagai bahan baku biogas semakin rendah kualitas pupuk organik cair yang dihasilkan. Hal ini disebabkan karena sludge lumpur aktif IPAL yang berasal dari limbah cair mengandung cukup banyak unsur hara dan bahan organik. Kandungan bahan organik dalam sludge lumpur aktif IPAL lebih banyak dibanding bahan organik lainnya. Dalam proses pembentukan gas metan atau biogas setelah diekstrak dari bahan organik, nitrogen dan hara lainnya tetap berada dalam limbah. Sehingga limbah yang dihasilkan mengandung banyak unsur hara yang bisa dimanfaatkan sebagai pupuk organik baik pupuk organik cair maupun pupuk organik padat. Penggunaan pupuk organik cair dari sludge lumpur aktif ternyata memperoleh hasil yang relatif sama dengan penggunaan pupuk kimia. Berbeda dengan penelitian yang dilakukan Sri Widyastuti dan Yogi Suyantara (2017) menunjukkan semakin banyak komposisi sampah sayuran maka tekanan gas juga semakin tinggi, pada hasil uji lama nyala api jika komposisi sampah sayuran semakin banyak maka lama nyala api semakin sedikit.

\section{KESIMPULAN}

Berdasarkan hasil penelitian yang telah dilaksanakan, mengacu pada hasil gas dan uji nyala ditarik kesimpulan bahwa biogas dapat dibuat dengan bahan baku sludge lumpur aktif IPAL, sampah dapur dan kotoran sapi. Hal ini dapat dibuktikan dengan uji nyala yaitu dari 3 variasi dengan 3 pengulangan hanya satu digester yang tidak terdeteksi. Variasi III memiliki waktu lebih cepat dalam menghasilkan gas. Hal ini ditunjukkan oleh kenaikan tekanan gas pada kolom air manometer selang "U".

Kualitas pupuk cair yang dihasilkan dengan parameter C Organik, N dan Salmonella ternyata dari 3 variasi ada 2 variasi yang menghasilkan pupuk cair sesuai SNI yaitu variasi II dan III. Sedangkan pada variasi I tidak memenuhi SNI Pupuk Organik Cair sesuai Peraturan Menteri Pertanian No. 70 / Permentan / SR.140 / $10 / 2011$.

\section{UCAPAN TERIMA KASIH}

Ucapan terima kasih dan penghargaan kami sampaikan kepada berbagai pihak yang telah memberikan bantuan berupa bimbingan, arahan, saran, dukungan dan kemudahan sejak awal sampai akhir penyusunan penelitian ini.

\section{DAFTAR PUSTAKA}

Ahmad, A. 2004. Studi Komperatif Sumber dan Proses Aklimatisasi Bakteri Anaerob Pada Limbah Cair Yang Mengandung Karbohidrat, Protein dan Minyak-Lemak. Jurnal Sains dan Teknologi Vol 3, No 1, Hal 1-10.

Ahmad, Risman. 2014. Estimasi Energi Kalor Biogas Dari Campuran Eceng Gondok Dan Kotoran Sapi. Artikel, Jurusan Fisika, Fakultas Matematika Dan IPA, Universitas Negeri Gorontalo, Gorontalo.

Anis Trisnaningsih dan Sri Widyastuti. 2015. Pencampuran Sampah Dapur Dan Daun Dengan Campuran Kotoran Sapi Untuk Pembuatan Biogas. WAHANA ISSN 0853-4403Volume 65, Nomer 2, 1 Desember 2015 halaman 24-32

Keputusan Gubernur Provinsi Jawa Timur No. 72 Tahun 2013. Baku Mutu Limbah Cair bagi Kegiatan Rumah Sakit di Provinsi Jawa Timur. 
Keputusan Menteri Kesehatan Republik Indonesia No.1204/MENKES/SK/X/2004 Tentang Persyaratan Kesehatan Lingkungan Rumah Sakit. Jakarta.

Mshandete A, Bjornsson, Kivaisi AK, Rubindamayugi MST, Mattiason B., 2006. Effect Of Particle Size On Biogas Yield From Sisal Fibre Waste. Jurnal Renewable Energy 31: 2385-2392.

Mujahidah, Mappiratu, Rismawaty S. 2013. Kajian Teknologi Produksi Biogas Dari Sampah Basah Rumah Tangga. Fakultas MIPA, Universitas Tadulako Online Jurnal of Natural Science, Vol. 2 (1): 25-34 ISSN: 2338-0950, Maret 2013

Ogbonna. C. B., Berebon. D. P., Onwuegbu. E. K.. Relationship between Temperature, Ph and Population of Selected Microbial Indicators during Anaerobic Digestion of Guinea Grass (Panicum Maximum). American Journal of Microbiological Research. 2015; 3(1):14-24. doi: 10.12691/ajmr-3-1-3. http://www.sciepub.com/reference/93384

Pambudi, N. A. 2008. Pemanfaatan Biogas Sebagai Energi Alternatif. Universitas Sebelas Maret, Surakarta. http://www.dikti.org/?q =node/99 [25 Feb 2008].

Peraturan Menteri Pertanian Nomor 70/Permentan/SR.140/10/2011 Tentang Pupuk Organik, Pupuk Hayati dan Pembenah Tanah. Jakarta.

Putro, S. 2007. Penerapan Instalasi Sederhana Pengolahan Kotoran Sapi Menjadi Energi Biogas Di Desa Sugihan Kecamatan Bendosari Di Kabupaten Sukoharjo.Warta. Vol:10(2)

Rahmi, Puji. 2010. Pembuatan Biogas dari Limbah Cair Domestik. Laporan Penelitian, Oktober 2010.

Santoso, Anugrah Adi. 2010. Produksi Biogas Dari Limbah Rumah Makan Melalui Peningkatan Suhu Dan Penambahan Urea Pada Perombakan Anaerob. Laporan Tugas Akhir, Fakultas MIPA, Universitas Sebelas Maret Surakarta.

SNI Pupuk Organik Cair Peraturan Menteri Pertanian No. 70 / Permentan / SR.140 / 10 / 2011.

Sri Widyastuti \& Yogi Suyantara. (2017) Penambahan Sampah Sayuran Pada Fermentasi Biogas Dari Kotoran Sapi Dengan Starter EM4. Jurnal Teknik WAKTU Volume 15 Nomor 1-Januari 2017-ISSN : 1412-1867 halaman 36-42

Sulistyo, Agung . 2010. Analisis Pemanfaatan Sampah Organik di Pasar Induk Kramat Jati Sebagai Pembangkit Listrik Tenaga Biogas. Tesis Program Magister Fakultas Teknik, Universitas Indonesia.

Sutrisno, Joko. 2010. Pembuatan Biogas Dan Bahan Sampah Sayuran (Kubis, Kangkung, Dan Bayam). Jurnal Teknik Waktu Volume 08 Nomor 01 Januari 2010- ISSN: 1412-1867, Teknik Lingkungan, Universitas PGRI Adi Buana, Surabaya.

Undang-Undang Republik Indonesia No.44 Tahun 2009 Tentang Rumah Sakit. 